\title{
ONENESS AND SELF-CENTEREDNESS IN THE MORAL PSYCHOLOGY OF WANG YANGMING
}

\author{
David W. Tien
}

\begin{abstract}
Rather than "selfishness," a more accurate and revealing interpretation of Wang's use of siyu 私欲 is "self-centeredness." One of the main goals in Wang's model of moral cultivation was to attain a state devoid of self-centered desires. Wang relied a great deal on the exercise and cultivation of an emotional identification and feeling of oneness with others. In this paper, I first provide a brief summary of the role of Wang's concept of siyu in his moral psychology. I then examine key passages in Wang's writings that reveal his nuanced understanding of siyu and, along the way, I draw on empirical research in psychology to help illuminate the significance of Wang's view of siyu to his overall model of moral cultivation.
\end{abstract}

KEY WORDS: Chinese philosophy, Wang Yangming, moral psychology, self-centeredness, selfishness, oneness

THE MORAL PSYCHOLOGY OF the Chinese scholar-official Wang Yangming (1472-1529) presents a compelling and nuanced vision of how people are at "one" with others and other parts of the world, and even with the universe at large. Wang focuses on the ethical implications that come from recognizing and living in light of such a conception of the self, especially in relation to how such a view entails or implies various types and levels of care for other people, creatures, and things. This essay describes Wang's conception of the self and explains its ethical implications, demonstrating how Wang's views can make significant contributions to contemporary debates about the ways we are and can see ourselves related to other people and the world. The teachings of Wang Yangming form the basis of what became known as “The Learning of the Mind" (xin xue 心學), one of the two leading schools of thought in the history of Neo-Confucianism, which dominated Chinese philosophy for over a thousand years. Wang's philosophy also greatly influenced the development of Confucian thought in Japan and Korea.

Almost all accounts of Wang Yangming's philosophy interpret his central concept of siyu 私欲 as “selfishness," which refers to a state of being almost exclusively or excessively concerned with one's own desires in contrast to others. A different interpretation of siyu would proceed in terms of

David W. Tien specializes in Chinese religion and philosophy. He earned his $\mathrm{Ph} . \mathrm{D}$. from the University of Michigan. He is currently an independent scholar in Singapore. David Tien, 18A Holland Drive, 38-457, Singapore 272018, dwtien@gmail.com 
"self-centeredness," which refers to taking the world excessively and exclusively from one's own point of view and to view oneself as distinctly separate from other persons and things. This paper argues that while Wang employed both senses of siyu and at times conflated them, and while there is some overlap between the two senses, a more accurate and revealing interpretation of Wang's use of siyu is "self-centeredness." One of the main goals in Wang's model of moral cultivation was to attain a state devoid of self-centered desires. Wang relied a great deal on the exercise and cultivation of an emotional identification and feeling of oneness with others. This was taken to such an extreme degree as to include experiencing an interpersonal unity with the entirety of Heaven and Earth. This is a state of oneness in which the conception of self and other are merged to a significant degree. These experiential states of oneness are causally responsible for motivating moral behavior.

In this paper, I first provide a brief summary of the role of Wang's concept of siyu in his moral psychology. I then examine key passages in Wang's writings that reveal his nuanced understanding of siyu and, along the way, I draw on empirical research in psychology-including the work of Robert Cialdini, C. Daniel Batson, and Arthur and Elaine Aron, among others-to help illuminate the significance of Wang's view of siyu to his overall model of moral cultivation.

\section{Siyu in the Moral Psychology of Wang Yangming}

Much of Wang Yangming's moral psychology hinges on his teaching regarding the liangzhi ("pure knowing"), which for him is the innate fully formed cognitive-affective-volitional faculty that enables one to know the $l i$ 理 (commonly translated as "principle") of the mind and universe. ${ }^{1}$ $L i$ denotes the way a thing or state of affairs ought to be. When things or states of affairs are not in accord with $l i$, they are deemed deviant. Every thing possesses all the $l i$ of the universe within it. In human beings, the $l i$ exists complete in the mind (xin 心). For Wang, though, the mind not only contains $l i$, the mind is itself $l i$ and operates as the knowing, conscious mode of $l i .^{2}$

At birth, we are endowed with this complete and perfect mind. Wang refers to this as the "mind in its original state" (xinzhibenti 心之本體) or the "original mind" (benxin 本心). The liangzhi operates as a cognitive-affectivevolitional faculty that discerns flawlessly, naturally, and spontaneously

\footnotetext{
${ }^{1}$ For my earlier version of this basic introduction to Wang's philosophy, see Tien 2004.

2 Translations of Wang are based on the Sibu Congkan 四部丵刊 edition. The number following the "S." corresponds to the section number in Chan's translation, which are given for ease of reference in Western libraries. Wang 1963, S. 118.
} 
between right and wrong, generating inerrant cognitive, affective, and volitional responses.

If our liangzhi is an infallible moral guide, how does Wang account for the bad moral choices we often seem to make? In line with the rest of the Neo-Confucian tradition, Wang explains moral wrong by invoking the concept of $q i$ 氣 (variously translated as "material force," "vital energy," or "lively matter") (Tien 2010b). ${ }^{3} Q i$ is the psychophysical stuff of which the universe is made. It exists in various grades of purity. For Wang and most Neo-Confucians, everything that exists is constituted by a combination of $l i$ and $q i$. Although all things possess all the $l i$ of the universe complete within them, because of the impurity of the $q i$ of which they are composed, some $l i$ are obstructed, thereby accounting for the differences between things. ${ }^{4}$ According to many Neo-Confucians, the high degree of clarity of the $q i$ of human beings enables us to purify our qi endowments, which would eventually allow all the $l i$ within us (or more accurately, within our minds) to shine forth. In turn, our pure and clear minds would be able to apprehend immediately and effortlessly the $l i$ in the external world.

Wang believes that the impure grades of $q i$ in human beings are manifested primarily as "self-centered desires" (si yu 私欲), which he also refers to as the "self-centered mind" (si xin), "self-centered ideas" (si yi), and "self-centered thoughts" (si nian). He believes that our self-centered desires obscure our grasp of our original minds and prevent us from utilizing our liangzhi faculties. For our liangzhi to operate at optimum effectiveness, first we would need to eliminate our self-centered desires. Wang employs Buddhist-inspired similes to illustrate the relation between the liangzhi and self-centered desires. Just as the sun shining behind clouds or a clear mirror hidden beneath dust, the liangzhi must be unobstructed by the "clouds" and "dust" of self-centered desires for it to apprehend $l i$ and lead us to correct moral decisions and affections. ${ }^{5}$

\section{Self-Centered or Selfish?}

How then does one discover and master one's grasp of this liangzhi faculty? The first necessary step is to pare away the siyu and thus attain a state of oneness, a state devoid of self-centeredness (Tien 2004). ${ }^{6}$ I use "self-centered" to contrast with what we usually mean by "selfish," which

\footnotetext{
${ }^{3}$ On the integral role of $q i$ in the philosophy of Wang, see Tien 2010b.

${ }^{4}$ For Wang's understanding of the Neo-Confucian slogan, " $L i$ is one but its manifestations are many," as well as for an explanation of the distinction in Wang between manifested and universal $l i$, see Tien $2010 \mathrm{~b}$.

${ }^{5}$ For the sun behind clouds imagery, see Wang 1963, S. 21, 62, 76, 167, and 171. For the mirror under dust imagery, see Wang 1963, S. 207, 237, 255, 289, and 290.

${ }^{6}$ For my earlier statement of this two-step process, see Tien 2004.
} 
is to be almost completely concerned with one's own good or pleasure above others'. "Self-centeredness" here means to view the world exclusively and excessively from one's own point of view. The perfect moral agent for Wang and other Neo-Confucians operates in a state of "oneness," a felt state of metaphysical unity in which one's sense of self is not so much lost than expanded. When acting in this state of oneness, one is not thinking about oneself at all. While this experiential state of oneness admits of degrees, in an ideal state of oneness, one would be completely unselfconscious and wholly unaware of any sense of personal agency. Wang's notion of self-centeredness arises from his belief in the underlying metaphysical unity of the universe, a notion he shares with almost all Neo-Confucians (Ivanhoe 2002, 28-30). For Wang, the liangzhi cannot operate freely and properly when it is impeded by these self-centered desires, so the first step is to eliminate them (Ivanhoe 2012). ${ }^{8}$

What is the relationship between "selfishness" and "self-centeredness"? I first came upon this distinction in the religious writings of C. S. Lewis, late professor of literature at Oxford and Cambridge Universities and prolific novelist. Lewis is often misleadingly characterized as a "popular" religious thinker. When this is meant in a derogatory sense, it usually betrays the peculiar academic prejudice against anyone who writes clearly and is widely read by others. With Lewis, however, one often encounters a strong dose of serious reflection, often in a charming literary style (Meilaender 1998).

In his autobiographical Surprised by Joy, Lewis characterized his ideal daily routine as "almost entirely selfish" but certainly not "self-centered." This ideal day was modeled on a "normal day" during his pre-university schooling. He paints a remarkably lucid and compelling picture of how a selfish but not self-centered man might go about his day. Lewis's ideal life would be spent from nine in the morning to seven in the evening mainly engaged in reading or writing about whatever interested him, with breaks for lunch and tea taken in solitude. ${ }^{9}$ While Lewis considered this his ideal

\footnotetext{
${ }^{7}$ The extent to which Wang's concept of siyu was related to the general discourse on desires in general and the specific notion of "selfish desires" in Ming-Qing literature and its cult of qing is an interesting question that unfortunately falls too far afield for this article. Thanks are due an anonymous reader for this suggestion. Clearly, siyu carried deep Buddhist connotations that would not have been lost on Wang's audience.

${ }^{8}$ For a masterly examination of the apparent paradox of how losing oneself can make oneself happy, see Ivanhoe 2012.

${ }^{9}$ Lewis 1955, 134-37: "[I]f I could please myself I would always live as I lived there. I would choose always to breakfast at exactly eight and to be at my desk by nine, there to read or write till one. If a good cup of tea or coffee could be brought me about eleven, so much the better.... At one precisely lunch should be on the table; and by two at the latest I would be on the road. Not, except at rare intervals, with a friend. Walking and talking are two very great pleasures, but it is a mistake to combine them. Our own noise blots out the sounds and
} 
day, he also demeaned it as selfish: "It is no doubt for my own good that I have been so generally prevented from leading it for it is a life almost entirely selfish. Selfish, but not self-centered," because, according to Lewis, "in such a life my mind would be directed toward a thousand things, not one of which is myself" (Lewis 1955, 137). Lewis gives himself as an example of someone who was once selfish but not self-centered.

Readily conceding that even if this "ideal" lifestyle were not selfcentered, it would still be selfish, Lewis nonetheless understands its attraction. And he recommends it over a life that is self-centered but not selfish:

One of the happiest men and most pleasing companions I have ever known was intensely selfish. On the other hand I have known people capable of real sacrifice whose lives were nevertheless a misery to themselves and to others, because self-concern and self-pity filled all their thoughts. Either condition will destroy the soul in the end. But till the end give me the man who takes the best of everything (even at my expense) and then talks of other things, rather than the man who serves me and talks of himself, and whose very kindnesses are a continual reproach, a continual demand for pity, gratitude, and admiration [Lewis 1955, 137].

In an epitaph he once composed, Lewis makes a similar point in a more playful style:

Erected by her sorrowing brothers

In memory of Martha Clay.

Here lies one who lived for others;

Now she has peace. And so have they [Lewis 2002, 134].

Here Lewis succinctly depicts a person who, under the guise of living for others, actually becomes their burden. Rather than being self-centered but not selfish, it would have been better for dear Martha to have been selfish in the manner described by Lewis, blithely following her own pleasures and desires without considering the viewpoints of others, than to be self-centered, focusing instead on things and events outside herself. If interpreted in light of his other writings on self-centeredness, one can

silences of the outdoor world; and talking leads almost inevitably to smoking, and then farewell to nature as far as one of our senses is concerned .... The return from the walk, and the arrival of tea, should be exactly coincident, and not later than a quarter past four. Tea should be taken in solitude,... [f] or eating and reading are two pleasures that combine admirably. Of course not all books are suitable for mealtime reading. It would be a kind of blasphemy to read poetry at table. What one wants is a gossipy, formless book which can be opened anywhere .... At five a man should be at work again, and at it till seven. Then, at the evening meal and after, comes the time for talk, or, failing that, for lighter reading; and unless you are making a night of it with your cronies . . . there is no reason why you should ever be in bed later than eleven.... Such then was my ideal and such then (almost) was the reality, of 'settled, calm Epicurean life." 
imagine Martha Clay as one who lived for others but talked of herself, whose very kindnesses were "a continual reproach, a continual demand for pity, gratitude, and admiration" (Lewis 1955, 137). And thus, according to Lewis, being self-centered is a greater sin than being merely selfish.

Like Lewis, I see a significant distinction between these two terms. To be "selfish" means to be almost exclusively or excessively concerned with one's own desires, though not necessarily with one's individual self. To be "self-centered" is to be almost exclusively or excessively concerned with one's individual self, though not necessarily with one's own desires. They are not mutually exclusive, but do come apart in key cases. Indeed, much overlap exists between these two categories. In many cases, people who are "self-centered" in this sense-that is, their thinking is engrossed almost entirely in themselves-are often at the same time "selfish," almost wholly concerned with their own wishes. But the concepts are nevertheless distinct.

For instance, consider the case of the smug philanthropist, who finds it easy and enjoyable to do kind and generous acts for other people. ${ }^{10}$ Unfortunately, he also takes great pride in his own attitude and actions, seeing them as expressions of his own moral greatness. Setting up his philanthropic foundation and generating much press coverage and promises of generous donations, this budding philanthropist arranges his first major fundraiser. When the donors finally meet him in person, though, they are so offended by his smugness that they choose to send their donations elsewhere. Here in the case of the smug philanthropist is an example of the converse of Lewis's idyllic "selfish but not self-centered" lifestyle. The smug philanthropist is unselfish-putting the desires and needs of others above his own-but intensely self-centered-thinking mainly about his own moral merit and magnanimity toward others. Neither of these states is ideal according to Wang and the Neo-Confucians. It would be best to be neither selfish nor self-centered.

But now we return to our earlier question. Was the siyu in Wang's siyu closer in meaning to "selfish" or "self-centered"? Some of the passages in which siyu occurs are ambiguous on this issue. Very likely, Wang himself was not clear on this distinction and occasionally conflated the two meanings. However, keeping the two separate is crucial to understanding why Wang gave siyu such a pivotal role in his philosophy of moral cultivation. While some key passages make more explicit Wang's interpretation of siyu as "self-centered," an equally cogent case for this view can be built upon the foundations of Wang's overall philosophy.

Along with most Neo-Confucians, and indeed most scholars during his time, Wang believed deeply in the underlying unity of the universe.

10 This example is inspired by one mentioned in personal correspondence with P. J. Ivanhoe. 
But this central idea was not confined to his metaphysics; it had farreaching ramifications for his ethics and moral psychology. Our oneness with all things in the universe held normative implications, as the early Neo-Confucian Zhang Zai (1020-77) proclaimed in his famous Western Inscription, which begins thusly:

Heaven is my father and Earth is my mother, and even such a small creature as I finds an intimate place in their midst. Thus, what fills the universe I regard as my body and what directs the universe I consider as my nature. All people are my brothers and sisters, and all things are my companions [Chan 1963, 497-98]. ${ }^{11}$

Zhang Zai and other Neo-Confucians did not employ this language of unity and oneness lightly. It was not meant to refer merely to the interconnectedness of human social networks, though that was of course included. The oneness of the universe was predicated on a common $q i$, the stuff of which all things are composed, and a common $l i$, the "heavenly pattern" (tianli 天理) that underlies all things in the universe.

In his celebrated essay, "Inquiry on the Great Learning," Wang invokes the theme of oneness in language similar to Zhang Zai's: "The great man regards Heaven, Earth, and the myriad things as one body. He regards the world as one family and the country as one person. As to those who make a cleavage between objects and distinguish between the self and others, they are small men" (Wang 1963, 272). The egregious error highlighted here is not a mere privileging of one's desires at the expense of others, but instead an excessive focus on one's individual self.

Wang saw this metaphysical unity as extending not only to people and animals, but also to plants and inanimate objects. He continues:

[W] hen he sees plants broken and destroyed, he cannot help a feeling of pity. This shows that his humanity forms one body with plants. It may be said that plants are living things as he is. Yet, even when he sees tiles and stones shattered and crushed, he cannot help a feeling of regret. This shows that his humanity forms one body with tiles and stones. This means that even the mind of the small man must have the humanity that forms one body with all. Such a mind is rooted in his Heaven-endowed nature and is naturally intelligent, clear, and not beclouded [Wang 1963, 272-73, translation modified].

Because even the uncultivated share their $q i$ and universal $l i$ in common with the rest of the universe, they too would feel pity and regret at the damage to plants, tiles, and stones, though they feel it to a much lesser degree than those who are morally cultivated. It is not that they feel hurt

11 This translation, with slight modifications, comes from Chan 1963, 497-98. My reading of the Xi Ming is based on the Sibu Beiyao edition. 
to see them damaged; they feel the hurt as their own, as a personal injury to an extension of their own bodies (Ivanhoe 2002, 29).

Elsewhere Wang expounds in detail on this theme:

\begin{abstract}
At bottom, Heaven and Earth and all things are my body. Is there any suffering or bitterness of the great masses that is not disease or pain in my own body? Those who are not aware of the disease and pain in their own body are people without the sense of right and wrong.... If gentlemen of the world merely devote their effort to extending their liangzhi, they will naturally share with all a universal sense of right and wrong, share their likes and dislikes, regard other people as their own persons, regard the people of other countries as their own family, and look upon Heaven, Earth, and all things as one body. When this is done, even if we wanted the world to be without order, it would not be possible. When the ancients felt that the good seemed to come from themselves whenever they saw others do good, when they felt that they had fallen into evil whenever they saw others do evil, when they regarded other people's hunger and drowning as their own, ... they did not purposely do so to seek people's faith in them .... Oh, how simple and easy was the way of sages to govern the empire [Wang 1963, S. 179]!12
\end{abstract}

The pain of others is the sage's pain. The guilt of others is the sage's guilt. The delight of others is the sage's delight. Wang's program of moral cultivation aimed to help us realize the sagehood within us all. And in reaching this goal, we too would feel this oneness with all things.

A well-known story of a founding father of Neo-Confucianism, Zhou Dunyi (1017-73), reported that he refused to cut the grass in front of his house because he felt intimately connected with it. ${ }^{13}$ In connection with this story, Wang averred, "The spirit of life of Heaven and Earth is the same in flowers and weeds" (Wang 1963, S. 101). Even more explicit in this regard is this passage from Cheng Hao's (1032-85) commentary on Analects 6:30:

In medical books, a paralyzed arm or leg is said to be "unfeeling" or "not benevolent" (buren 不仁). This expression is perfect for describing the situation. The benevolent person, or "one with feeling" (ren), regards all things in the universe as one body. There is nothing that is not [a part of] him. If he regards all things as [parts of] himself, to where will [his feelings] not extend? However, if he does not see them [as parts of] himself, why would he feel any concern for them? It is like the case of a paralyzed arm or leg. The $q i$ does not circulate through them, so they are not regarded as parts of

12 Compare, Mengzi 7A: 15.

13 Adduced in Wang 1963, S. 101. Compare, 65n20. The story is recorded in the Cheng brothers' Henan Chengshi Yishu, 3:2a. 
oneself .... Kongzi sought to lead us to see benevolence in this manner so that we could attain benevolence itself [Ivanhoe 2002, 28, translation modified]. ${ }^{14}$

This interpretation of "benevolence," as a sort of sensitivity towards all parts of the one, universal body, is as Ivanhoe describes, "the ethical expression of Wang's metaphysical beliefs" (Ivanhoe 2002, 28). Forming one body with the universe consists in first cognitively comprehending the underlying unity and then experiencing the concomitant feeling of a pervasive unity with the cosmos and all its constituent parts.

Clearly, then, overcoming one's self-centeredness-one's focus on one's personal self to the exclusion of all others-is a necessary step in one's journey to sagehood. In his "Inquiry on the Great Learning," Wang elaborated on this link:

Hence, if it is not obscured by self-centered desires, even the mind of the small man has the humanity that forms one body with all as does the mind of the great man. As soon as it is obscured by self-centered desires, though, even the mind of the great man will be divided and narrow like that of the small man. Thus, the learning of the great man consists entirely in getting rid of the obscuration of self-centered desires in order by his own efforts to make manifest his clear character, so as to restore the condition of forming one body with Heaven, Earth, and the myriad things [Wang 1963, 273, translation modified].

Thus, for Wang, the goal was to eliminate one's self-centeredness and expand one's sense of self to embrace all of reality. This entailed a loss of one's "self" apart from other people and things. Self-centeredness, then, was a pernicious and persistent impediment to the moral life. That is why destroying "self-centered desires," which draw a false distinction between one's individual self and the rest of the universe, is the way to preserve Heavenly $l i$ and finally form one body with Heaven, Earth, and the myriad things.

One might object that Wang at times does recommend focusing on one's own life and world. After all, Wang teaches that in the process of self-cultivation, we are to work on precisely those tasks that confront us in our daily lives (Ivanhoe 2002, 100-2). But in this case, Wang does not mean focusing on the self in contrast to focusing on other persons. Rather, the contrast is between directing one's thoughts, emotions, and actions toward some abstract ideal versus directing them toward being moral in the concrete circumstances in which one already finds oneself. He admonishes us to focus first on being good moral persons in our everyday situations rather than leaving behind our duties and responsibilities to

14 Translation from Ivanhoe 2002, 28 (with slight modifications). Translation based on Sibu Beiyao edition, Henan Chengshi Yishu 2A:2a, b (compare, 2A:15b). 
seek some great heroic task far off. ${ }^{15}$ Here he displays his Chan Buddhist proclivities in his emphasis on concrete practice in everyday life. And Wang's emphasis on being good and doing right in the conditions that confront us in daily life resonates with Mother Teresa's sentiment, "It is easy to love people far away. It is not always easy to love those close to us. It is easier to give a cup of rice to relieve hunger than to relieve the loneliness and pain of someone unloved in our own home. Bring love into your home for this is where our love for each other must start" (Scott 2001, 62; attributed to Mother Teresa of Calcutta).

Moreover, while being un-self-centered may be the aim of selfcultivation, there is an intermediate stage entailing that one's self be at the center of one's moral world. Along these lines, Wang urges his students to monitor their own thoughts and feelings, "like a cat catching mice," always trying to identify and eliminate any self-centered or selfish thoughts that arise (Tien 2010a). This requires a high level of self-scrutiny and necessarily involves extended and intensive periods of focus on oneself. But this is only necessary when one's liangzhi faculty of pure knowing is not yet properly functioning (Tien 2004, 46-49). Once one's liangzhi is unimpeded by siyu and is functioning properly, one would naturally think, feel, and do the right things, effortlessly and naturally. Admittedly, the attainment of this advanced stage of moral development is rare, hence, Wang's emphasis on self-monitoring.

Although "self-centeredness" more accurately captures the sense and significance of siyu for Wang instead of "selfishness," Wang himself may have been unaware of this distinction in the two meanings of si. I readily admit that sometimes Wang uses the term in the sense of a straightforward "selfishness." Perhaps the clearest instance of this is a passage in which Wang inveighs against the loss of liangzhi in his generation. $\mathrm{He}$ laments how "people have used their selfishness $(s i)$ and cunning to compete and clash with one another.... Outwardly, people make pretenses in the name of humanity and rightness. At heart, their real aim is to act for their own benefit" (Wang 1963, S. 180, translation modified). In this case, siyu must mean placing one's own desires first at the expense of others' and hence "selfish" is a correct translation.

But perhaps Wang saw selfishness as one expression of selfcenteredness, for later in the same passage, in excoriating these hypocrites, Wang attributes their moral failings to a lack of understanding and affective appreciation for their oneness with the universe:

They indulge in passions and give free rein to self-centered desires, and yet regard themselves as sharing the same likes and dislikes with the rest of mankind .... Even among blood relatives, they cannot get rid of the feeling

15 Thanks are due to an anonymous reader for leading me to this point. 
of mutual separation and obstruction. How much more will this be true in regard to the great multitude and the myriad things? How can they regard them as one body? No wonder the world is confused, and calamity and disorder endlessly succeed each other [Wang 1963, S. 180].

Thus, for Wang, not only was experiential knowledge of one's unity with all things characteristic of the ideal state, it was also a prime motivator in generating moral action. Here one sees the connection between siyu and the doctrine of the "unity of knowledge and action" (zhixing heyi). Wang blames self-centered desires for the unfortunate separation of knowledge and action: "The knowledge and action you refer to are already separated by self-centered desires and are no longer knowledge and action in their original substance" (Wang 1963, S. 5) ${ }^{16}$ But why would self-centered desires be the main obstacle separating knowledge from action?

\section{Oneness and Moral Motivation}

In recent decades, psychologists, not content to leave the study of altruism and moral motivation to the philosophers, have examined the question of whether we are ever genuinely selfless. In response to the leading hypothesis on this subject at the time, Robert Cialdini and his research associates proposed and tested a theory that attributes helping behavior to self-other merging. While it is outside the bounds of this paper to take sides on this debate, it is instructive to highlight resonances between the self-other merging theory and Wang Yangming's theory of self-centeredness and moral motivation. ${ }^{17}$

In recent decades, the most intense discussions in this area of psychology have repeatedly invoked the concept of empathy. One of the most prominent and research productive of the empathy-based formulations of altruism has been that of C. Daniel Batson. ${ }^{18}$ According to Batson's empathy-altruism hypothesis, purely altruistic acts can occur consistently if they are preceded by the specific psychological state of empathic concern for the other. They define "empathic concern" as an emotional reaction characterized by feelings described as compassion, tenderness, softheartedness, and sympathy. In an extensive program of research involving scores of experiments over multiple decades, they and other researchers

\footnotetext{
16 See also Wang 1963 , S. 8.

${ }^{17}$ For a pioneering study of the philosophical psychology of oneness and self that draws on Neo-Confucianism, see Ivanhoe 2010.

${ }^{18}$ See especially Batson 1991. For his most recent study, see Batson 2009, 3-15. On empathy and moral motivation, see also Hoffman 2000. For an excellent recent analysis of empathy in philosophy, see Slote 2007. For a superb treatment of empathy in Neo-Confucian thought, see Angle 2009.
} 
working independently ${ }^{19}$ have demonstrated that generally, under conditions of empathic concern for the other, individuals help more frequently in what appear to be altruistically motivated attempts to improve the other's well-being rather than an egoistically motivated attempt to improve their own. Their empathy-altruism hypothesis has been repeatedly confirmed in the face of challenges from various egoistically based alternative accounts, such as those attributing helping behavior to reward seeking, punishment avoidance, aversive arousal reduction, as well as an egoistic desire to escape social disapproval, guilt, shame, sadness, or to increase vicarious joy. ${ }^{20}$ Even major advocates of egoistic accounts of helping have conceded that there is credible experimental evidence for the existence of genuine altruism (Archer 1984; Piliavin and Chang 1990; and Cialdini et al. 1997).

However, Cialdini and associates presented evidence challenging the empathy-altruism model, proposing instead a theory based on the merging of self and other identity. ${ }^{21}$ Their conclusion denied the existence of pure altruism because altruism depends critically on the separateness of the self and the other. Without a distinct self and other and without distinct motivations to aid the self or the other, it would be impossible to detach altruism from egoism, a line of reasoning that Batson and associates acknowledged. Self-other merging may never actually be complete and total, so that there is always room for the possibility (even if very minor) of altruism. However, as the self and other increasingly merge, helping the other increasingly helps the self. When the distinction between self and other is undermined, the old dichotomy between selfishness and selflessness no longer applies. Earlier research also suggested that the merging of self and other identity can explain helping behavior and that such merging can occur and most likely under the same conditions linked by the empathy-altruism model to feelings of attachment and altruistic motivation.

Building on earlier research by Arthur and Elaine Aron, Mark H. Davis, and others, Cialdini and associates tested their self-other merging hypothesis in three studies closely resembling the conditions under which Batson and associates tested their empathy-altruism model, using perspective taking instructions and the variable of relationship closeness (Aron and Aron 1986; Aron, Aron, and Smollan 1992; Aron, Aron, Tudor, and Nelson 1991; and Davis et al. 1996). On four categories of closeness-from near stranger to acquaintance to good friend to close family member-as subjects took the perspective of those closer to them, the degree to which

19 Compare Dovidio, Allen, and Schroeder 1990.

${ }^{20}$ For a summary of this research, see Batson 1991, 91-174.

${ }^{21}$ This debate unfolds in Cialdini, et al. 1997; Batson et al. 1997; Neuberg et al. 1997; and Batson 1997. 
they were willing to offer help increased dramatically compared to the degree of empathic concern they felt. That is, "controlling for oneness eliminated the influence of empathic concern, whereas controlling for empathic concern left oneness a powerful predictor of willingness to help" (Cialdini et al. 1997, 485). ${ }^{22}$ Their path analysis revealed further that empathy increased willingness to help only through its relation to perceived oneness, suggesting that empathy affects helping primarily as an emotional signal of oneness, thereby undermining the altruism-empathy model.

The research cited by Cialdini and associates characterized "oneness" in terms such as identity and psychological indistinguishability (Lerner 1982), expansion of the self to include the other, confusion between self and other, union, merging (Aron, Aron, and Smollan 1992), and the preferred description of Cialdini and associates, as seeing part of oneself in another. ${ }^{23}$ According to Cialdini and associates, oneness and empathy are bidirectional. The perception of oneness can generate the experience of empathy, and the experience of empathy can generate the perception of oneness. But it is oneness and not empathy that motivates helping. Empathic concern is thus merely a concomitant of oneness.

The psychologists' findings also support the evolutionary perspective on helping that holds that as indications of genetic commonality between individuals increase, so will willingness to assist, especially in higher need situations where survival is at risk. This also dovetails with recent discussions of biological altruism, which differs in kind from the psychological altruism Cialdini and associates are attacking. ${ }^{24}$ This is consistent with Neo-Confucian claims that the $q i$ of blood relatives bear similarities that the $q i$ of non-relatives do not share, and thus only a blood relative can call back the dispersed $q i$ of a deceased ancestor. ${ }^{25}$ This is the metaphysical argument underlying the Neo-Confucian support for the traditional Chinese emphasis on and preference for family and filial piety.

Moreover, the psychologists' conclusions fit well with the psychological literature on concepts of "self" in non-Western societies, in which a more communal rather than individualistic orientation is common (Nisbett 2003; Markus and Kitayama 1991; Triandis 1989; Gilligan 1982; and Geertz 1973). Corroborating their data on oneness and helping, earlier studies on Asian societies found that Asians showed a greater willingness

\footnotetext{
${ }^{22}$ Notice the shift in wording between "oneness" and "relationship closeness," a point Batson picks up in his critique in 1997, 518-19.

${ }^{23}$ Cialdini and associates later prevaricate on this description of "oneness," and Batson criticizes them for it. Batson 1997, 517-18.

${ }^{24}$ For a classic treatment of this distinction, see Sober and Wilson 1998.

${ }^{25}$ For example, see Gardner 1995; and Tillman 2004.
} 
than those in Western societies to help in-group members and a lesser willingness to help out-group members (Leung 1998). Since those from Asian cultures supposedly imbue more of the self-concepts into their groups, in a very real sense, what they do to and for others, they do to and for themselves.

Other studies have shown that a deep experience of oneness can cause people to act as if some or all aspects of the other are partially their own, and this is sometimes accompanied by a sense of a general increase of fusion between the self and the other. For instance, Aron and Aron's self-expansion model holds that people are motivated to enter and maintain close relationships to expand the self by including the resources, perspectives, and characteristics of the other in the self (Aron and Aron 1986). Similarly, other studies on group oneness have demonstrated the powerful effect of group identification on participants' willingness to restrict individual gain to preserve collective good. Positive evaluations and liking for others can be induced simply by the knowledge of a shared, common identity. This is a phenomenon that researchers have called "depersonalized social attraction," and it is closely connected to the idea of a "social self" that is a more inclusive self-representation in which relations and similarities to others become central to one's self concept (Hogg 1992; Brewer and Gardner 1996).

In recent decades, research in neuroscience has unearthed the operation of mirror neurons. ${ }^{26}$ Often, empathy-altruism theorists claim that the work of mirror neurons confirms their position. While the process of simulation by which mirror neurons seem to operate may be consistent with simulation theories of empathy, the very fact that we have such strong neural connections with others lends considerable support to the oneness hypothesis. The human brain has multiple systems of mirror neurons, with more being discovered over time, and there seem to be a great number of such neural systems that have not yet been mapped. Our brains have a multitude of mirror neuron systems that automatically and unconsciously cause us to mimic others' actions, interpret others' intentions, extract the social implications of events, and read and adopt others' emotions. ${ }^{27}$ The instant triggering of parallel circuitry in two brains enables us to establish a shared experiential world. Daniel Stern, a developmental psychiatrist, has researched extensively the relationships between mothers and infants, as well as those between adults, such as the relationships between lovers and between therapists and clients. Stern points out that our nervous systems "are constructed to be captured by the nervous systems of others, so that we can experience others as if from

${ }^{26}$ On the discovery of mirror neurons, see di Pellegrino, et al. 1992.

${ }^{27}$ For a generally accessible introduction to this research, see Goleman 2006, 38-49. 
within their own skin" (Stern 2004, 76) ${ }^{28}$ At such times, we automatically, immediately, and unconsciously experience a kind of oneness with others, and they with us. Stern's conclusion is remarkably reminiscent of NeoConfucian claims of oneness. We can no longer "see our minds as so independent, separate, and isolated," but must instead perceive them as "permeable," constantly interacting with the others around us (Stern 2004, 76).

In Neo-Confucian religious ethics, the experience of oneness plays an integral role in motivating moral behavior, for while empathy and oneness are closely linked, Wang and many other Neo-Confucians seem to say that oneness and not empathy leads to moral motivation. Although NeoConfucians ground this state of oneness in their li-qi metaphysics, contemporary psychologists understand this in a much more mundane sense. Despite the similarities in their descriptions with Neo-Confucianism, the psychological literature refers mainly to the oneness experienced between blood relatives, extended family, close friends, and coherent groups. Wang and other Neo-Confucians would no doubt have wholeheartedly supported the findings of Cialdini et al., and it would be instructive to elucidate how oneness, and not empathy, could motivate helping behavior in a contemporary case. ${ }^{29}$

Take, for example, the case of a football player on a cohesive team. In the middle of a game, he sees his teammate suddenly attacked flagrantly, unfairly, and excessively by a player on the opposing team. He and most of his teammates react naturally and spontaneously. They are immediately motivated to help their teammate. He is one of them. He is part of the team. The teammates do not proceed by empathic or vicarious roletaking, considering what it would be like to be attacked by an opposing player in just such a manner, how they would feel in his shoes, and then what they would like their teammates to do in response. Rather, they perceive him as one of them. It is the oneness from identifying themselves as part of a unitary team that leads to the motivation and helping behavior.

If, as Wang Yangming maintains, the perception and experience of oneness is the primary factor motivating moral behavior, then it should

${ }^{28}$ Also quoted in Goleman 2006, 43.

${ }^{29}$ If, however, "empathy" were to be defined so broadly as to encompass "oneness" as Cialdini and associates use it, then the empathy-altruism model would of course still hold. The overly broad semantic range that Hoffman grants to his use of "empathy" reflects this and allows him to brush over the debate between Batson and Cialdini et. al. (Hoffman 2000). See also the brief explanation by Michael Slote for why he chooses to rely on Hoffman's work over Batson's, which permits him an excessively wide reach for his category of "empathy" and papering over the problems that the oneness hypothesis presents for the empathyaltruism theory (Slote 2007, 13-15). 
be clear why self-centeredness is so dangerous. ${ }^{30}$ Self-centeredness drives a wedge between the individual self and the rest of the world. So even if people grasp cognitively that they should act filially to their parents, unless they perceive and experience their oneness with their parents, they will not be induced to act lovingly to them. Put another way, unless they have experiential knowledge of their oneness with their parents, they will not feel a strong compulsion to act filially toward them.

When one feels a collective unity with another, one naturally takes into account the other's needs and desires and is as motivated to help the other as one is to help oneself. In teaching about the principle of filial piety, Wang draws this connection: "If the mind is free from self-centered human desires and has become completely identical with the Heavenly Principle,...then in the winter, one will naturally think of how cold one's parents feel and seek to provide warmth for them, and in the summer, one will naturally think of how hot the parents feel and seek to provide coolness for them" (Wang 1963, S. 3, translation modified).

At an even more basic level, being in an experiential state of oneness just is being in accord with $l i$ : "What is the difference between being in accord with $l i$ and having no self-centered mind?' The Teacher said, 'The mind is $l i$. To have no self-centered mind is to be in accord with $l i$, and not to be in accord with $l i$ is to have a self-centered mind" (Wang 1963, S. 94, translation modified). So the goal of Neo-Confucian epistemology and moral cultivation is to attain and sustain the experiential state of oneness. Wang's theory of knowledge and action posits that moral action naturally ensues from the oneness state. So the crucial step is achieving and living in the experience of oneness. Wang's si cannot merely be "putting one's desires above those of others." It is a deeper philosophical concept, integrally related to the underlying unity of the universe, a metaphysical doctrine to which Wang and other Neo-Confucians were deeply committed. ${ }^{31}$

\section{Conclusion}

To recapitulate, while Wang's concept of si likely encompassed both interpretations, the more significant role in Wang's moral psychology was held by "self-centeredness." The necessary first step in Wang's model of

${ }^{30}$ While not addressing the difference between empathy-altruism and the oneness hypothesis, Michael Slote nevertheless rightly points out Wang's prescience here in anticipating Hume's discussion of sympathy by more than a couple of centuries (Slote 2009).

${ }^{31}$ Wang extended the experiential state of oneness to cover plants and inanimate objects. For an insightful treatment of this aspect of Wang's theory of oneness, see Ivanhoe 2010, $15-16$. 
moral cultivation was to achieve a state of oneness, devoid of self-centered desires. This was predicated on Wang's basic metaphysics, which held to the underlying unity of the universe. The state of oneness enables one to experience an emotional identification and a feeling of interpersonal unity with the entirety of Heaven and Earth, including other living things and even inanimate objects. In this state of oneness, the conception of self and other are not distinct but are instead merged. The realization and affective appreciation of our oneness with all things holds such significance in Wang's moral philosophy because this experience of oneness is causally responsible for motivating moral behavior. Wang's insights on oneness resonate with contemporary research by Cialdini, Aron, and others on the psychology of helping behavior, which argues for the oneness theory over the empathy-altruism hypothesis.

\section{REFERENCES}

Angle, Stephen C.

2009 Sagehood: The Contemporary Significance of Neo-Confucian Philosophy. New York: Oxford University Press.

Archer, Richard L.

1984 "The Farmer and the Cowman Should Be Friends: An Attempt at Reconciliation with Batson, Coke, and Pych." Journal of Personality and Social Psychology 46: 709-11.

Aron, Arthur, and Elaine N. Aron

$1986 \quad$ Love and the Expansion of Self: Understanding Attraction and Satisfaction. Washington, D.C.: Hemisphere Publishing Company.

Aron, Arthur, Elaine N. Aron, and Danny Smollan

1992 "Inclusion of Other in the Self Scale and the Structure of Interpersonal Closeness." Journal of Personality and Social Psychology 63: $596-612$.

Aron, Arthur, Elaine N. Aron, Michael Tudor, and Greg Nelson

1991 "Close Relationships as Including Other in the Self." Journal of Personality and Social Psychology 60: 241-53.

Batson, C. Daniel

1991 The Altruism Question: Toward a Social-Psychological Answer. Hillsdale, N.J.: Lawrence Erlbaum Associates, Inc.

1997 "Self-Other Merging and the Empathy-Altruism Hypothesis: Reply to Neuberg et al." Journal of Personality and Social Psychology 73: $517-22$.

2009 "These Things Called Empathy: Eight Related but Distinct Phenomena." In The Social Neuroscience of Empathy, edited by Jean Decety and William Ickes, 3-15. Cambridge, Mass.: MIT Press. 
Batson, C. Daniel, Karen Sager, Eric Garst, Misook Kang, Kostia Rubchinsky, and Karen Dawson

1997 "Is Empathy-Induced Helping Due to Self-Other Merging?" Journal of Personality and Social Psychology 73: 495-509.

Brewer, Marilynn B., and Wendi Gardner

1996 "Who Is This 'We'? Levels of Collective Identity and Self Representations." Journal of Personality and Social Psychology 71: 83-93.

Chan, Wing-tsit

1963 A Source Book in Chinese Philosophy. Princeton, N.J.: Princeton University Press.

Cialdini, Robert B., Stephanie L. Brown, Brian P. Lewis, Carol Luce, and Steven

L. Neuberg

1997

"Reinterpreting the Empathy-Altruism Relationship: When One into One Equals Oneness." Journal of Personality and Social Psychology 73: 481-94.

Davis, Mark H., Laura Conklin, Amy Smith, and Carol Luce

1996 "The Effect of Perspective Taking on the Cognitive Representation of Persons: A Merging of Self and Other." Journal of Personality and Social Psychology 70: 713-26.

di Pellegrino, Giuseppe, Luciano Fadiga, Leonardo Fogassi, Vittorio Gallese, and Giacomo Rizzolatti

1992 "Understanding Motor Events: A Neurophysiological Study." Experimental Brain Research 91: 176-80.

Dovidio, John F., Judith Allen, and David A. Schroeder

1990 "The Specificity of Empathy-Induced Helping: Evidence for Altruism." Journal of Personality and Social Psychology 59: 249-60.

Gardner, Daniel K.

1995 "Ghosts and Spirits in the Sung Neo-Confucian World: Chu Hsi on kuei-shen." Journal of the American Oriental Society 115.4: 598-611.

Geertz, Clifford

1973 The Interpretation of Cultures. New York: Basic Books.

Gilligan, Carol

1982 In a Different Voice: Psychological Theory and Women's Development. Cambridge, Mass.: Harvard University Press.

Goleman, Daniel

2006 Social Intelligence: The New Science of Human Relationships. London: Arrow Books.

Hoffman, Martin L.

2000 Empathy and Moral Development: Implications for Caring and Justice. New York: Cambridge University Press.

Hogg, Michael A.

1992 The Social Psychology of Group Cohesiveness: From Attraction to Social Identity. London: Harvester Wheatsheaf.

Ivanhoe, Philip J.

2002 Ethics in the Confucian Tradition: The Thought of Mengzi and Wang Yangming. 2nd ed. Indianapolis, Ind.: Hackett Publishing Co., Inc. 
2010 "Senses and Values of Oneness." Manuscript.

2012 "Happiness in Early Chinese Thought." In Oxford Handbook of Happiness, edited by Ilona Boniwell and Susan David. New York: Oxford University Press, forthcoming.

Lerner, Melvin J.

1982 "The Justice Motive in Human Relations and the Economic Model of Man." In Cooperation and Helping Behavior: Theories and Research, edited by Valerian Derlaga and Janusz Grzelak, 249-78. New York: Academic Press.

Leung, Kwok

1988 "Theoretical Advances in Justice Behavior: Some Cross-Cultural Inputs." In The Cross-Cultural Challenge to Social Psychology, edited by Michael H. Bond, 218-39. Newbury Park, Calif.: Sage.

Lewis, Clive S.

1955 Surprised by Joy: The Shape of My Early Life. New York: Bruce Harcourt.

2002 Poems. Fort Washington, Pa.: Harvest Books.

Markus, Hazel Rose, and Shinobu Kitayama

1991 "Culture and Self: Implications for Cognition, Emotion, and Motivation.” Psychological Review 98: 224-53.

Meilaender, Gilbert

1998 “The Everyday C. S. Lewis.” First Things (August/September).

Neuberg, Steven L., Robert B. Cialdini, Stephanie L. Brown, Carol Luce, and Brad J. Sagarin

1997 "Does Empathy Lead to Anything More than Superficial Helping? Comment on Batson, et al." Journal of Personality and Social Psychology 73: 510-16.

Nisbett, Richard

2003 The Geography of Thought: How Asians and Westerners Think Differently... and Why. New York: Free Press.

Piliavin, Jane Allyn, and Hong-Wen Chang

1990 "Altruism: A Review of Recent Theory and Research," American Sociological Review 16: 27-65.

Scott, David

2001 A Revolution of Love: The Meaning of Mother Teresa. Chicago, Ill.: Loyola Press.

Slote, Michael

2007 The Ethics of Care and Empathy. New York: Routledge.

2009 "Comments on Bryan Van Norden's Virtue Ethics and Consequentialism in Early Chinese Philosophy." Dao: A Journal of Comparative Philosophy 8: 291-93.

Sober, Elliot and David S. Wilson

1998 Unto Others: The Evolution and Psychology of Unselfish Behavior. Cambridge, Mass.: Harvard University Press. 
Stern, Daniel

2004 The Present Moment in Psychotherapy and Everyday Life. New York: W. W. Norton.

Tien, David W.

2004 "Warranted Neo-Confucian Belief: Religious Pluralism and the Affections in the Epistemologies of Wang Yangming (1472-1529) and Alvin Plantinga." International Journal for Philosophy of Religion 55: $31-55$.

2010a "Like a Cat Catching Mice': Neo-Confucian Cognitive Therapy." Manuscript.

2010b "Metaphysics and the Basis of Morality in the Philosophy of Wang Yangming." In Neo-Confucian Philosophy, edited by John Makeham, 295-314. New York: Springer.

Tillman, Hoyt C.

2004 "Zhu Xi's Prayers to the Spirit of Confucius and Claim to the Transmission of the Way." Philosophy East and West 54.4: 489-513.

Triandis, Harry C.

1989 "The Self and Social Behavior in Differing Cultural Contexts." Psychological Bulletin 96: 506-20.

Wang, Yangming

1963 Instructions for Practical Living and Other Neo-Confucian Writings by Wang Yangming. Based on Wang Wenchenggong quanshu edition of 1572. Translated with notes by Wing-tsit Chan. New York: Columbia University Press. 